\title{
The Protective Effects of Green Tea Catechin on The Bleomycin and Cyclophosphamide Induced Cytotoxicity
}

\author{
Yong Lim \\ Department of Clinical Laboratory Science, Dong-eui University, Busan 614-714, Korea
}

\begin{abstract}
Green tea and tea polyphenols have been studied extensively as cancer chemopreventive agents in recent years. Epigallocatechin-3-gallate (EGCG) is widely recognized as a powerful antioxidant and a free radical scavenger. The purpose of this study was to evaluate the protective effects of green tea catechins (GTC) on the Bleomycin- and Cyclophosphamide-induced cytotoxicity. Cell viability was measured by MTT assay. In the protective effect of GTC, the cell viability was significantly increased by the treatment of GTC. Furthermore, GTC showed the higher protective effect than EGCG and vitamin E. These results suggest that GTC has the protective effect which is related to the prevention of cancer. Our studies show that the continuous presence of EGCG can reduce radical-induced DNA damage in Chinese hamster lung fibroblast cells (CHL cells).
\end{abstract}

Keywords: GTC, Bleomycin, Cyclophosphamide, Cytotoxicity

This is an Open Access article distributed under the terms of the Creative Commons Attribution Non-Commercial License (http://creativecommons.org/licenses/by-nc/3.0) which permits unrestricted non-commercial use, distribution, and reproduction in any medium, provided the original work is properly cited.

Copyright @ 2014 The Korean Society for Clinical Laboratory Science. All rights reserved.
Corresponding author: Yong Lim

Department of Clinical Laboratory Science,

Dong-eui University, Busan 614-714, Korea Tel: 82-51-890-2684

E-mail: yonglim@deu.ac.kr

Received: June 14, 2014 Revised: June 26, 2014 Accepted: June 30, 2014

\section{서 론}

최근에 oxidative stress에 의한 돌연변이, 염색체 손상으로 비 롯된 암(cancer)과 노화(aging) 억제제를 천연물로부터 찾아내는 일에 매우 관심이 커지고 있다. 녹차 추출물에 대한 항산화효과에 대한 연구는 주로 폴리페놀성분에 대하여 많이 이루어 졌는데, 함 유카테킨들의 2,2'-azo-bis (2-amidinopropane) dihydrochloride (AAPH)에 의한 azo 프리라디칼 유도 적혈구 용혈에 대한 효과 (Zhang 등, 1997), 다양한 중국산 차로부터 제조된 폴리페놀성분 의 항산화효과(Ho 등, 1992), 녹차유래 항산화성물질들의 암 예방 효과(Katiyar와 Mukhtar, 1997), 녹차추출물의 hydroxyl radical 과 superoxide anion scavenging activity (Noda 등, 1997), 녹차 카테킨류의 lipid peroxidation에 대한 억제효과(Guo 등, 1996), hydroxyl radical에 의한 DNA break에 대한 억제효과(Hiramoto 등, 1996), 1,2-dimethylhydrazine 유도 산화적 DNA 손상에 대 한 보호효과(Inagake 등, 1995) 등이 알려지고 있다.

녹차추출물은 항산화작용과 hydroxyl radical, superoxide anion 등을 소거함으로서 산화적 스트레스에 대한 보호작용을 하 고 있다. 생체에서 생성된 hydroxyl radical은 대단히 반응성이 높
다. 또한 생체는 superoxide도 생성하지만 이것은 비교적 반응성 이 낮다. 이러한 superoxide는 $\mathrm{Fe}$ 와 $\mathrm{Cu}$ 존재하에서 hydroxyl radical을 만들며 nitric oxide와 결합하여 peroxynitrite가 되고 이것이 분해하여 nitrogen dioxide gas, hydroxyl radical과 nitronium을 생성하기도 한다(Chance 등, 1979). 이렇게 생성된 ROS들은 생체내에서 superoxide dismutase가 superoxide를 hydrogen peroxide로 변화시키고, catalase는 hydrogen peroxide 를 제거한다. 한편 glutathione transferase와 glutathione peroxidase들은 친전자성 이물을 포합하여 해독하며 SOD에 의해 생성된 peroxides를 제거한다. 그러나 생체내에서 완화한 oxidative stress가 일어나면 세포들은 이러한 항산화기전을 가동 하여 반응하지만 심한 oxidative stress는 세포의 injury와 death 를 일으키며 이러한 cell death는 necrosis와 apoptosis로 발전된 다(Ames, 1983).

$\mathrm{ROS}$ 에 의한 oxidative DNA damage는 암과 노화와 관련이 깊 다. 이들은 point mutation이나 deletion을 포함하는 돌연변이를 nuclear DNA에서 일으키며 mitochondrial DNA에서의 oxidative damage는 노화세포에서의 에너지 결핍을 일으켜 나이 에 따라 돌연변이의 축적이 일어난다. 따라서 DNA수복의 결핍은 
세포사를 일으키고 이것은 인접세포들에 있어서 carcinogenesis 로의 촉진적 자극을 일으키게 한다(Ames, 1983).

산화적 DNA손상을 통하여 발암의 전단계에서 일어나는 돌연변 이나 염색체 손상 등의 유전독성에 대한 억제물질들은 암의 initiation, promotion 및 progression 단계에서 항산화반응을 통 한 세포내 대사의 modulation, DNA 반응성 물질들의 blocking, DNA replication 이나 DNA repair modulation 작용과 같은 기전 으로 돌연변이나 염색체 손상 및 암을 예방할 수 있는 것으로 기대 되고 있다(De Flora 등, 1992).

따라서, 본 연구에서는 사람들이 섭취하는 녹차중에서 다양한 유전독성억제활성이 밝혀진 녹차카테킨류 GTC와 EGCG를 대상 으로 하여 in vitro에서 햄스터 폐 섬유아세포(Chinese hamster lung fibroblast cell) 독성유발제로 잘 알려진 bleomycin과 cyclophosphamide로 유도된 세포독성을 측정하여 세포독성의 보호작용을 확인하고자 하였다.

\section{재료 및 방법}

\section{1. 녹차카테킨 (GTC)의 제조}

보성다원 차나무(Camellia sinensis L.)의 잎 $100 \mathrm{~g}$ 을 취하여 $70 \%$ ethanol 1,000 mL로 90 95 $5^{\circ} \mathrm{C}$ 에서 3시간 1차 추출 후에 $70 \%$ ethanol $500 \mathrm{~mL}$ 로 같은 조건에서 3시간 2차 추출을 완료한 후 녹차의 고형성분을 압착하여 제거하고, 추출액을 합하여 vacuum rotary evaporator에서 $45^{\circ} \mathrm{C}$ 로 약 $100 \mathrm{~mL}$ 가 될 때까지 농축했다. 농축액을 $\mathrm{H}_{2} \mathrm{O}$ 로 2 3배 희석시킨 후 $23,700 \times \mathrm{g}$ 에서 20 분간 원심분리하여 고형성분을 완전히 제거한 후 모아진 상층액 에 대하여 1.2 배의 chloroform으로 2회 추출한 다음 chloroform 층을 버리고 수층에 대한 1.2배의 ethylacetate로 4회 추출하여 얻 은 액을 합한 후 ethylacetate가 완전히 없어질 때까지 감압 건고 시 켰다. 다시 소량의 물로 용해시킨 후 동결 건조하여 녹차카테킨 (GTC) 분말을 얻었다. 이 GTC는 건조엑스로서 $1 \mathrm{~g}$ 이 약 $10 \mathrm{~g}$ 에 상 당하며, 건조물을 정량하면 총 카테킨류를 $75 \%$ 이상 함유하고 그 중 epigallocatechin gallate ( $\mathrm{EGCG} ; \mathrm{C}_{22} \mathrm{H}_{18} \mathrm{O}_{11}$ )가 $25 \%$ 이상을 함유했다.

\section{2.세포 및 배양방법}

포유동물 세포인 Chinese hamster lung fibroblasts ( $\mathrm{CHL}$ )을 $5 \% \mathrm{CO}_{2}$ 배양기에서 $37^{\circ} \mathrm{C}$ 온도로 $10 \%$ fetal bovine serum (FBS, $\mathrm{GIBCO}$ )과 $1 \%$ glutamine (GIBCO), $1 \%$ penicillin-streptomycin (GIBCO)이 포함된 Eagle's minimum essential medium (EMEM, $\mathrm{GIBCO})$ 에 단층 배양하여 사용하였다. 한편, primary cell culture
를 위해서는 C57BL mouse splenocyte를 분리하여 실험하였다. C57BL/6 마우스(male, $15 \sim 25 \mathrm{~g}$ )로 부터 무균적으로 비장을 적출 하여 일회용 $50 \mathrm{~mL}$ 무균주사기의 plunger를 이용하여 세포를 분 리시킨 후 cell count하여 $20 \times 10^{6} \mathrm{cell} / \mathrm{mL}$ 로 만들었다. 이 세포현 탁액 $0.5 \mathrm{~mL}$ 씩을 배지에 가하여 실험하였다.

\section{3. 세포독성 보호작용}

햄스터 폐 섬유아세포(Chinese hamster lung fibroblast cells) 에 있어서의 독성유발제로서 강력한 발암물질인 bleomycin과 cyclophosphamide의 세포독성에 대한 녹차추출물들의 효과를 MTT법에 따라 microplate reader로 측정하였다. 이때 CHL cell 은 well 당 25,000 개로 하고 $10 \% \mathrm{FBS}, 2 \%$ L-glutamine, $2 \%$ penicillin-streptomycin 함유 EMEM 배지 $80 \mu \mathrm{L}$ 중에서 24시간 배양 후 bleomycin 또는 cyclophosphamide $10 \mu \mathrm{L}$ 및 검체 $10 \mu \mathrm{L}$ 를 가하고 $\mathrm{CO}_{2}$ incubator에서 20시간 더 배양한 후 MTT 시약 15 $\mu \mathrm{L}$ 를 가하고 4 시간 배양 후 $\mathrm{DMSO}$ 를 $200 \mu \mathrm{L}$ 가하고 녹인 후 570 $\mathrm{nm}$ 에서 흡광도를 측정하였다.

\section{4. 통계처리}

본 실험에서의 결과치 유의성은 Student's t-test를 이용하여 $p$ $<0.05$ 와 $p<0.01$ 에서 유의성을 검정하였다.

\section{결과 및 고찰}

본 연구에서는 강력한 발암물질인 bleomycin과 cyclophosphamide의 세포독성에 대한 녹차추출물들의 세포독성 억제 효과를 검토하였다.

Bleomycin은 Umezawa 등에 의해 만들어진 당단백질로서 세

Table 1. The protective effect of green tea catechin (GTC) on the bleomycin-induced cytotoxicity in CHL cells

\begin{tabular}{lclc}
\hline & $\begin{array}{c}\text { Treatment } \\
(\mu \mathrm{g} / \mathrm{mL})\end{array}$ & \multicolumn{1}{c}{ OD $570 \mathrm{~nm}$} & Cell viability (\%) \\
\hline GTC & 0 & $0.838 \pm 0.204$ & 100 \\
& 10 & $0.872 \pm 0.104$ & 104 \\
& 50 & $1.257 \pm 0.156^{\star \star}$ & 149 \\
EGCG & 100 & $1.262 \pm 0.046^{\star \star}$ & 150 \\
& 0 & $0.838 \pm 0.204$ & 100 \\
& 10 & $1.120 \pm 0.169^{\star \star}$ & 133 \\
Vitamin E & 50 & $1.183 \pm 0.279^{\star \star}$ & 141 \\
& 100 & $0.952 \pm 0.293$ & 113 \\
& 0 & $0.485 \pm 0.195$ & 100 \\
& 10 & $0.368 \pm 0.066$ & 75 \\
& 50 & $0.478 \pm 0.074$ & 98 \\
& 100 & $0.537 \pm 0.119$ & 110 \\
\hline
\end{tabular}


포의 DNA와 결합하여 세포에 독성 작용을 하며 주로 편평상피암 및 악성림프종 등에 함암제로서 사용되고 있으며 부작용으로 폐 간 질 섬유증을 야기시킨다(Ingenito 등, 2001). Hsu 등(1989)에 의 해 변이소 감수성 연구에 대한 표준화된 분석방법이 소개되어 짧은 시간의 노출에도 분열 중기 염색체의 염색분체 파손을 많이 초래하 고 이러한 파손은 염색체를 따라 임의로 골고루 분포하기 때문에 시험변이소로 적합하다(Hus 등, 1985; Hus 등, 1990).

Table 1에 나타낸 것처럼 녹차추출물(GTC)은 bleomycin 유도 세포독성에 대하여 $10 \sim 100 \mu \mathrm{g} / \mathrm{mL}$ 처리농도에서 무처리군에 비 하여 $150 \%$ 까지의 세포생존율 증가를 농도의존적으로 유의성있게 나타내었다 $(* * * 0.01)$. GTC는 혼합물임에도 불구하고 프리라디 칼 발생제로서 발암성을 나타내는 bleomycin에 대하여 EGCG나 Vitamin E 보다 높은 세포생존율의 증가를 나타내었다.

Bleomycin에 의한 DNA 손상 복구에 관여하는 효소계에 대한 정확한 정보는 아직 없다. 따라서 GTC에 의한 세포보호작용으로 치료 효과를 높일 수 있으리라 기대되며, GTC에 의해 염색체 감수 성으로 나타나는 부작용을 억제하는 기전에 대해 자세히 설명할 수 없지만 이를 입증하기 위한 전향적 연구가 필요하리라 생각된다.

Cyclophosphamide는 세포독성을 지닌 알킬화 약물로, 여러 악성 종양 및 장기 이식뿐만 아니라 전신성 홍반성 루푸스를 포함 한 여러 자가면역질환에 사용되고 있다(Levine과 Richie, 1989). 루푸스는 대부분의 고형암 발생을 증가시키지 않는다고 알려져 있으나, 루푸스와 같은 면역 질환에서 cyclophosphamide로 치료 하였을 때 투여된 총용량과 기간에 따라 요로내피세포에 손상을 일 으켜 방광암 발생에 관여할 수 있다(Abu-Shakra 등, 2002).

Table 2에 나타낸 것처럼 GTC는 cyclophosphamide 유도 세 포독성에 대하여 10 100 $\mu \mathrm{g} / \mathrm{mL}$ 처리 농도에서 무처리군에 비하 여 $128 \%$ 까지의 세포생존율의 증가를 나타내었다(* $p<0.05)$. Vitamin E 보다는 활성이 낮았으나 EGCG가 활성이 없는 것에 비

Table 2. The protective effect of green tea catechin (GTC) on the cyclophosphamide-induced cytotoxicity in CHL cells

\begin{tabular}{lccc}
\hline & $\begin{array}{c}\text { Treatment } \\
(\mu \mathrm{g} / \mathrm{mL})\end{array}$ & OD $_{570 \mathrm{~nm}}$ & Cell viability (\%) \\
\hline GTC & 0 & $1.493 \pm 0.247$ & 100 \\
& 10 & $1.914 \pm 0.078^{\star}$ & 128 \\
& 50 & $1.875 \pm 0.614$ & 125 \\
EGCG & 100 & $1.907 \pm 0.614$ & 127 \\
& 0 & $1.492 \pm 0.249$ & 100 \\
& 10 & $1.186 \pm 0.732$ & 79 \\
Vitamin E & 50 & $0.959 \pm 0.302$ & 64 \\
& 100 & $1.255 \pm 0.436$ & 84 \\
& 0 & $0.263 \pm 0.109$ & 100 \\
& 10 & $0.489 \pm 0.124^{\star *}$ & 185 \\
& 50 & $0.683 \pm 0.388^{\star *}$ & 259 \\
\hline
\end{tabular}

하여 GTC는 혼합물임에도 불구하고 알킬화제로서 발암성을 나타 내는 cyclophosphamide에 대하여 세포생존율의 증가를 나타내 었다.

이상의 결과들로 녹차추출물은 bleomycin과 cyclophosphamide 에 의한 세포독성에 대한 강력한 세포보호작용을 나타내었다. 따라 서 세포독성을 억제시키는 세포독성보호제로서의 응용가능성이 높은 물질로 사료된다.

Acknowledgements: None

Funding: None

Conflict of interest: None

\section{References}

1. Abu-Shakra M, Ehrenfeld M, Shoenfeld Y. Systemic lupus erythematosus and cancer: associated or not?. Lupus. 2002, 11: 137-144.

2. Ames BN. Dietary carcinogens and anticarcinogens. Oxygen radicals and degenerative diseases. Science. 1983, 221:1256-1264.

3. Chance B, Sies H, Boveris A. Hydroperoxide metabolism in mammalian organs. Physiol Rev. 1979, 59:527-605.

4. De Flora S, Bronzetti G, Sobels FH. Assessment of antimutagenicity and anticarcinogenicity. Mutat Res. 1992, 267: 153-155.

5. Guo Q, Zhao B, Li M, Shen S, Xin W. Studies on protective mechanisms of four components of green tea polyphenols against lipid peroxidation in synaptosomes. Biochim Biophys Acta. 1996, 13:210-222.

6. Hiramoto K, Ojima N, Sako K, Kikugawa K. Effect of plant phenolics on the formation of the spin-adduct of hydroxyl radical and the DNA strand breaking by hydroxyl radical. Biol Pharm Bull. 1996, 19:558-563.

7. Ho CT, Chen Q, Shi H, Zhang KQ, Rosen RT. Antioxidative effect of polyphenol extract prepared from various Chinese teas. Prev Med. 1992, 21:520-525.

8. Hsu TC, Cherry LM, Samaan NA. Differential mutagen susceptibility in cultured lymphocytes of normal individuals and cancer patients. Cancer Genet Cytogenet. 1985, 17:307-313.

9. Hsu TC, Johnston DA, Cherry LM, Ramkissoon D, Schantz SP, Jessup JM, Winn RJ, Shirley L, Furlong C. Sensitivity to genotoxic effects of bleomycin in humans: possible relationship to environmental carcinogenesis. Int J Cancer. 1989, 43:403-409.

10. Hsu TC, Shillitoe EJ, Cherry LM, Lin Q, Schantz SP, Furlong C. Cytogenetic characterization of 20 lymphoblastoid lines derived from human individuals differing in bleomycin sensitivity. In Vitro Cell Dev Biol. 1990, 26:80-84.

11. Inagake M, Yamane T, Kitao Y, Oya K, Matsumoto H, Kikuoka N, Nakatani H, Takahashi T, Nishimura H, Iwashima A. Inhibition of 1,2-dimethylhydrazine-induced oxidative DNA damage by green tea extract in rat. Jpn J Cancer Res. 1995, 86:1106-1111.

12. Ingenito EP, Mora R, Cullivan M, Marzan Y, Haley K, Mark L, 
Sonna LA. Decreased surfactant protein-B expression and surfactant dysfunction in a murine model of acute lung injury. AmJ Respir Cell Mol Biol. 2001, 25:35-44.

13. Katiyar SK, Mukhtar H. Tea antioxidants in cancer chemoprevention. J Cell Biochem Suppl. 1997, 27:59-67.

14. Levine LA, Richie JP. Urological complications of cyclophosphamide. J Urol. 1989, 14:1063-1069.

15. Noda Y, Anzai K, Mori A, Kohno M, Shinmei M, Packer L.
Hydroxyl and superoxide anion radical scavenging activities of natural source antioxidants using the computerized JES-FR30 ESR spectrometer system. Biochem Mol Biol Int. 1997, 42: 35-44.

16. Zhang A, Zhu QY, Luk YS, Fung KP, Chen ZY. Inhibitory effects of jasmine green tea epicatechin isomers on free radical-induced lysis of red blood cells. Life Sci. 1997, 61:384-394. 